\title{
Nilai Eksklusivitas Dalam Karya Foto Cover Majalah Tempo Edisi 4351 Tentang Kasus Bom Sarinah 2016
}

\author{
Yohanes Christiansen Tanjung, Rustono Farady Marta \\ Program Studi Ilmu Komunikasi - Fakultas Ilmu Sosial dan Humaiora (FISH) \\ Universitas Bunda Mulia \\ yohctanjung@gmail.com, rustonofarady@gmail.com,
}

\begin{abstract}
Visualization towards a news which is not limited on animation or photographic works in electronic media, online, and printed media has purposively been as additional information and becomes a complement of news. Particularly in spot news of the photojournalism works, every occurrence happens quite quickly. Due to photography, every moment can be recorded and well documented, as well as providing answers to what is actually happening on a rapid occurrence. One example is the use of photographs on a printed media, namely Tempo. This Research aims to observe hidden meaning in the works of photojournalism on the cover of Tempo magazine 4351 edition wether it is objective or subjective meaning that be received by the public after seeing the photo on the cover. The method used is descriptive qualitative method by conducting analysis of Peirce semiotics on the cover photo of Tempo magazine issue of 4351. Based on the research which has been done, it can be concluded that the application of visualization conducted by Tempo referred to the works of photojournalism in the cover of Tempo magazine issue of 4351 created exclusivity both in objective and subjective meaning
\end{abstract}

Keywords: exclusivity, journalistic photography, mass media, semiotics

\begin{abstract}
Abstrak
Visualisasi pada suatu pemberitaan baik itu animasi maupun karya foto dalam media elektronik, online, dan pastinya media cetak, mempunyai tujuan sebagai informasi tambahan serta pemanis suatu berita. Khususnya pada karya foto jurnalistik spot news, setiap peristiwa yang terjadi dengan sangat cepat. Oleh karena fotografi, setiap kejadian dapat direkam dan didokumentasikan dengan baik, serta memberikan jawaban atas apa yang sebenarnya terjadi pada suatu peristiwa yang berlangsung dengan cepat. Salah satu contohnya adalah pemakaian karya foto pada sebuah cover media cetak, yaitu Tempo. Penelitian bertujuan untuk mengetahui makna yang tersembunyi dalam karya foto jurnalistik pada cover majalah Tempo edisi 4351 baik berupa makna obyektif maupun subyektif yang diterima publik setelah melihat foto pada cover tersebut. Metode yang dipakai adalah metode kualitatif deskriptif dengan melakukan analisis semiotika Peirce pada foto cover majalah Tempo edisi 4351. Berdasarkan penelitian yang telah dilakukan, dapat disimpulkan bahwa penerapan visualisasi yang dilakukan oleh Tempo mengacu pada karya foto jurnalistik dalam cover majalah Tempo edisi 4351 menciptakan nilai eksklusivitas baik itu dalam makna obyektif maupun subyektif.
\end{abstract}

Kata Kunci: eksklusivitas, fotografi jurnalistik, media massa, semiotika 


\section{Pendahuluan}

Majalah Tempo merupakan media massa cetak nasional di indonesia yang membahas tentang ekonomi serta politik yang berkecamuk di Indonesia. Majalah yang selalu terbit mingguan ini menyasar kepada segmentasi kelas menengah ke atas, artinya pada segmentasi ini, masyarakat menginginkan suatu media cetak yang dikemas sesuai kebutuhan dan keinginan seperti, baik politik, ekonomi, sosial, dan budaya, berarti dalam penyajiannya sangat terstruktur serta ditunjang dengan pemakaian kata baku dan berpendidikan. Dikemas sedemikian rupa agar nilai berita yang disajikan, menjadikannya salah satu sumber informasi panutan majalah di Indonesia. Tidak mengherankan, jika berita-berita yang disampaikan majalah Tempo sarat dengan ilmu pengetahuan bahkan selalu terdepan dalam mengangkat suatu permasalahan baik dalam dunia ekonomi maupun politik nasional.

Perlu waktu yang panjang, mulai dari sekedar ilustrasi, penguat tulisan, hingga foto disandingkan dengan sebuah berita. Foto dapat lebih berbicara dibanding tulisan. Tulisan mengandung beberapa makna, tetapi foto mengandung berjuta ungkapan tersirat tergantung kepada siapa yang melihatnya, tetapi juga, foto dapat mewakilkan semua tulisan yang ada (Wijaya, 2014).

Majalah Tempo sebagai media cetak yang selalu terbit mingguan, dituntut sedemikian rupa untuk mengabarkan berita akurat tanpa mengorbankan isi dan gagasan dalam pesan. Hal inilah yang membuat majalah Tempo harus lebih kritis terhadap permasalahan-permasalahan atau fenomena-fenomena yang terjadi dalam satu minggu untuk dikemas dalam berita atau topik utama. Terlebih foto yang akan dimasukan ke dalam cover serta headline foto.

Dalam beberapa tahun terakhir, media massa baik itu cetak, siaran sampai media online, setiap harinya membahas tentang ekonomi serta politik. Ada pro, dan juga ada kontra. Hal ini dikarenakan adanya keberpihakan atau buah pemikiran suatu media akan fenomena atau kejadian yang ada. Termasuk pada kasus bom Sarinah yang terjadi pada tanggal 14 Januari 2016 menjadi cover serta headline utama pada media massa seluruh Indonesia, salah satunya majalah Tempo.

Kasus itu terkait pada teror oleh teroris, dengan adanya beberapa granat yang meledak di daerah Sarinah, Jakarta Pusat, serta baku tembak antara polisi dengan para teroris. Kejadian terjadi sekitar pukul 10 pagi tersebut sangat cepat dan pada saat jam kerja, artinya terdapat banyak masyarakat yang lalu lalang di sekitar tempat kejadian, dan benar, diberitakan secara langsung oleh stasiun televisi indonesia di jakarta, kejadian tersebut mengakibatkan jatuhnya beberapa korban jiwa serta belasan warga, baik itu warga negara Indonesia sampai warga negara asing menjadi korban dari aksi teroris.

Berdasarkan berita yang dikutip di majalah.tempo.co, kejadian yang terjadi pada saat jam kerja itu terjadi di beberapa titik di daerah Sarinah dan dengan waktu hanya berselang beberapa menit sampai pada akhirnya terjadi adu tembak serta bom bunuh diri oleh teroris. Dikarenakan adanya jeda pada satu bom dengan bom yang lain sampai pada baku tembak, mengakibatkan banyaknya warga sekitar yang ingin melihat serta mengabadikan momen kejadian di salah 
satu tempat terjadinya bom meledak, yaitu di pos polisi Sarinah melalui foto dan video.

Kejadian ini langsung dijadikan kesempatan emas untuk para pewarta foto untuk mengabadikan momen tersebut, khususnya pewarta foto di majalah Tempo. Pewarta foto majalah Tempo dengan intuisinya sebagai fotografer jurnalistik berhasil mengabadikan beberapa momen-momen pelaku teroris yang sedang menembakkan senjata api di sekitar kerumunan masyarakat dan beberapa polisi.

Pada kasus ini pula, foto di cover majalah Tempo edisi 4351, tanggal 1824 Januari 2016 dihiasi hasil foto dari pewarta foto Tempo. Dalam foto cover majalah tersebut (tampak pada Gambar 1), terlihat seorang teroris sedang memegang senjata api menembaki seorang polisi di daerah perutnya. Foto pada cover majalah Tempo itu akhirnya menjadi buah bibir dalam dunia jurnalistik bahkan sampai diadakan seminar membahas benarkah cover majalah Tempo tersebut sesuai dengan kode etik jurnalistik atau tidak dikarenakan mempertontonkan visualiasi yang dianggap terlalu keras dan berdampak pada citra polisi- Hal ini menyatakan, bahwa sebuah cover foto bukan hanya sebatas pemanis halaman depan, tetapi menjadi kesan tersendiri untuk opini publik tercipta, bukan hanya sebatas tulisan. Selain itu, sebuah foto dalam konteks jurnalistik dapat dipakai dalam sebuah cover majalah yang dilihat secara nasional, hal tersebut mengidentifikasikan adanya sebuah keunikan dan nilai berita yang sangat tinggi pada foto yang diperoleh oleh majalah Tempo dalam dokumentasi aksi teror bom di daerah Sarinah, Jakarta 14 januari 2016.

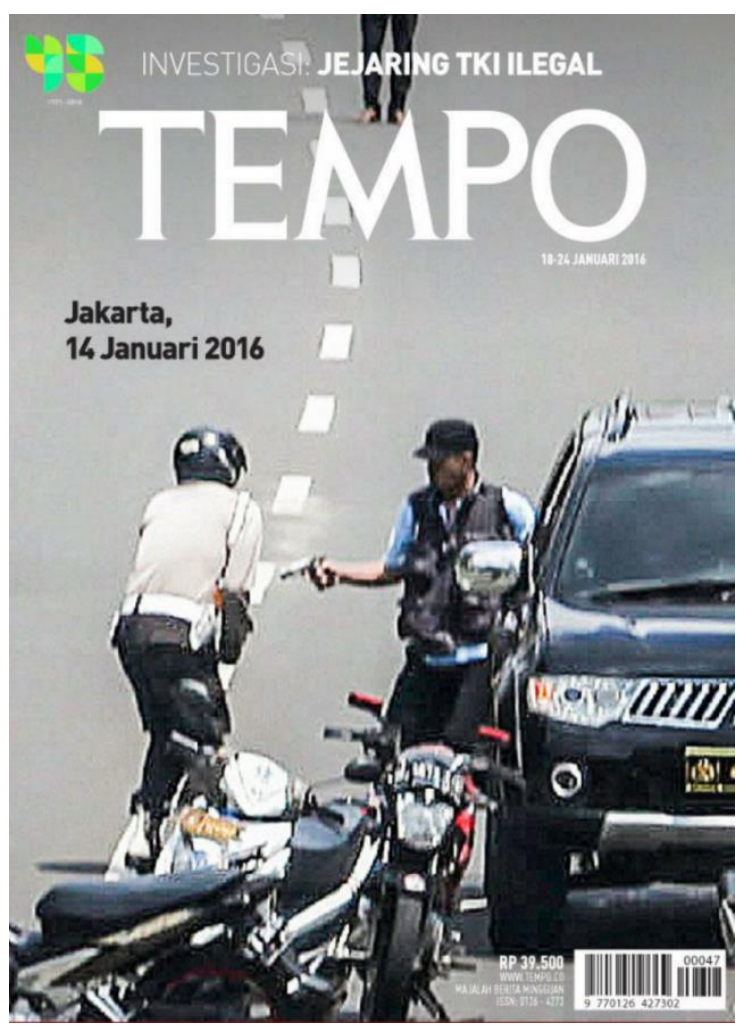

Gambar 1: Cover Majalah Tempo Edisi 4351 
Foto cover dalam sebuah media cetak, termasuk pada majalah Tempo, dilihat dari pengkategorian fotografi, termasuk dalam bentuk fotografi jurnalistik. Fotografi jurnalistik, sebagai salah satu dari berbagai bidang fotografi yang ada, terdapat hal khusus yang harus hadir dalam sebuah karya foto jurnalistik, bukan hanya dilihat dari estetikanya, tetapi juga dari nilai berita. Nilai berita yang dimaksud adalah sebuah pengungkapan berita melalui foto yang mengandung unsur $5 \mathrm{~W}+1 \mathrm{H}$ (what, who, where, when, why, dan how) guna memberikan pesan yang semakin kuat terhadap berita yang disampaikan, yaitu berupa tulisan dan visual.

Fotografi jurnalistik selain mengandung isi berita dan estetika, harus mencerminkan etika dan norma hukum yang ada, agar dapat mencakup setiap aspek serta elemen-elemen kehidupan masyarakat. Foto memberikan arti serta gagasan, juga merekam kejadian-kejadian dengan ketepatan yang lebih tinggi dari pada yang dilakukan manusia. Foto juga dapat mendukung berita khususnya dalam media cetak, ketika tulisan dalam sebuah berita tidak mampu menggambarkan realita yang terjadi. Foto semakin dianggap penting dalam dunia jurnalistik yang semakin berkembang di Indonesia. Hal tersebut dikarenakan, menurut Taufan (dalam Wijaya, 2014). foto yang terdapat dalam cover suatu media cetak baik surat kabar, tabloid, dan majalah, menjadi utama pada saat ingin membeli atau memasuki halaman berikutnya, dikarenakan seseorang akan melihat visual pada cover terlebih dahulu. Tulisan mempunyai arti dari setiap kata-kata, tetapi foto mempunyai berjuta-juta makna pada sepasang mata yang melihatnya.

Sebuah karya foto secara umum merupakan salah satu aspek penting bagi kehidupan manusia, bukan hanya sekedar visual semata, melainkan sudah mengalami pergeseran dari fungsi secara sederhananya untuk memperlihatkan sebuah visualisasi yang terekam, sampai pada fungsi lain, yaitu mewakilkan suatu penyampaian atau pesan tersirat dari setiap detil visual sehingga mempunyai makna tersendiri bagi siapa saja yang melihatnya.

Pada hakikat sebagian manusia, hal yang melekat dan tidak bisa dipisahkan manusia dengan visual, karena manusia sebagai makhluk sosial seringkali dipertemukan atau ditempatkan pada suatu keadaan yang tidak dapat diungkapkan melalui kata-kata atau lisan, maka dari itu, visual sebagai salah satu alternatif manusia berkomunikasi. Visual dapat berupa karya lambang, desain grafis, murral, dan salah satunya berupa foto (Safanayong, 2011).

Wartawan foto sama seperti wartawan tulis, menyampaikan pesan. Wartawan tulis menyampaikan pesan lewat tulisan, wartawan foto lewat foto yang dihasilkan dan dimuat media cetak, kemudian juga media non cetak. Fotografi jurnalistik tidak hanya masalah teknis fotografi, tetapi juga pesan.

Hal ini dikarenakan dari sekian banyaknya foto yang sudah direkam oleh para pewarta foto, maka akan dipilih satu yang menjadi headline foto di surat kabar yang akan dicetak keesokan harinya. Foto tersebut pastinya harus mempunyai nilai berita sangat tinggi pada kejadian yang sedang hangatnya diperbincangkan untuk disampaikan kepada para pembaca. Oleh karena itu, sebuah foto yang terdapat pada headline foto harus sesuai dengan pemberitaan yang ada dan tidak adanya perubahan melalui proses olah digital. 
Fungsi sebuah foto, mengalami pergeseran dalam penyampaian suatu pesan. Bukan hanya sekedar foto, tetapi tersirat seperti apa yang diinginkan oleh buah pemikiran majalah Tempo itu sendiri.

Mengacu kasus tersebut, penelitian bertujuan untuk melakukan analisis pada nilai eksklusifitas pada foto cover tentang bom Sarinah pada majalah Tempo edisi 4351. Ini dikarenakan, foto pada cover majalah Tempo menjadi unsur pertama para pembaca dalam mengimplementasikan isi berita terlebih foto cover majalah tersebut kontroversial.

Charles Sanders Pierce adalah seorang ahli matematika dari Amerika Serikat yang sangat tertarik pada persoalan lambang-lambang. Pierce menggunakan istilah representamen yang tidak lain adalah lambang (sign) dengan pengertian sebagai something which stands to somebody in some respect or capacity (Sobur, 2006).

Dalam Sobur (2006), Pierce menggunakan teori segitiga makna (triangle meaning) yang terdiri atas: (1) Sign (Tanda), adalah suatu fisik yang dapat ditangkap oleh panca indera manusia dan merupakan sesuatu yang merujuk (pemaknaan) hal lain dari luar tanda itu sendiri. (2) Object (Obyek), adalah konteks sosial yang menjadi referensi dari tanda atau sesuatu yang dirujuk tanda. (3) Interpretant (Interpretan) adalah konsep pemikiran dari orang yang menggunakan tanda dan menurunkannya ke suatu makna yang ada dalam benak seseorang tentang obyek yang ditunjuk sebuah tanda.

Upaya klasifikasi yang dilakukan oleh Pierce terhadap tanda memiliki kekhasan meski tidak bisa dikatakan sederhana. Tanda merupakan sesuatu yang berbentuk fisik yang dapat ditangkap oleh panca indera manusia dan merupakan sesuatu yang merujuk hal lain di luar tanda itu sendiri. Tanda menurut Pierce (dalam Wibowo, 2011) terdiri dari Ikon (Tanda yang muncul dari perwakilan fisik), Indeks (Tanda yang muncul dari hubungan sebab-akibat), dan Simbol (Tanda yang muncul dari kesepakatan). Berikut dijelaskan lebih rinci, di mana: (1) Ikon adalah tanda yang mengandung kemiripan 'rupa' sehingga tanda itu mudah dikenali oleh para pemakainya. Di dalam ikon, hubungan antara representamen dan obyeknya terwujud sebagai kesamaan dalam beberapa kualitas; (2) Indeks adalah tanda yang memiliki keterkaitan fenomenal atau eksistensial di antara representamen dan obyeknya. Di dalam indeks, hubungan antara tanda dengan obyeknya bersifat konkret, aktual, dan biasanya melalui suatu cara yang sekuensial atau kausal; (3) Simbol merupakan jenis tanda yang bersifat abriter dan konvensional sesuai kesepakatan atau konvensi sejumlah orang atau masyarakat. Tanda-tanda kebahasaan pada umumnya adalah simbol-simbol.

Penelitian juga menggunakan konstruksi sosial, di mana individu menciptakan secara terus-menerus suatu realitas yang dimiliki dan dialami bersama secara subyektif. Realitas tidak dibentuk secara ilmiah, tidak juga sesuatu yang diturunkan oleh Tuhan. Tetapi sebaliknya, ia dibentuk dan dikonstruksi. Dikarenakan sifat dan faktanya bahwa pekerjaan media massa adalah menceritakan peristiwa-peristiwa, maka kesibukan utama media massa adalah mengkonstruksikan berbagai realitas yang akan disiarkan (Hamad, 2004). Media menyusun realitas dari berbagai peristiwa yang terjadi hingga menjadi cerita atau wacana yang bermakna. Pembuatan berita di media pada dasarnya adalah 
penyusunan realitas-realitas hingga membentuk sebuah cerita atau wacana yang bermakna. Dengan demikian, seluruh isi media tiada lain adalah realitas yang telah dikonstruksikan dalam bentuk wacana yang bermakna.

Setiap orang yang mempunyai pengalaman, preferensi, pendidikan tertentu, dan lingkungan pergaulan atau sosial tertentu akan menafsirkan realitas sosial itu dengan konstruksinya masing-masing. Ada tiga tahap dalam konstruksi sosial, yaitu (1) Eksternalisasi, Usaha pencurahan atau ekspresi diri manusia ke dalam dunia, baik dalam kegiatan mental maupun fisik. Manusia berusaha menangkap dirinya, dalam proses inilah dihasilkan suatu dunia dengan kata lain, manusia menemukan dirinya sendiri dalam suatu dunia. (2) Obyektivasi, hasil yang telah dicapai baik mental maupun fisik dari kegiatan eksternalisasi manusia tersebut. Hasil itu menghasilkan realitas obyektif yang bisa jadi akan menghadapi si penghasil itu sendiri sebagai suatu faktisitas yang berada di luar dan berlainan dari manusia yang menghasilkannya. Realitas obyektif itu berbeda dengan kenyataan subyektif perorangan. Ia menjadi kenyataan empiris yang bisa dialami oleh setiap orang. (3) Internalisasi, proses internalisasi lebih merupakan penyerapan kembali dunia obyektif ke dalam kesadaran sedemikian rupa sehingga subyektif individu dipengaruhi oleh struktur dunia sosial. Melalui internalisasi, manusia menjadi hasil dari masyarakat.

Dalam penelitian ini, foto adalah unsur utama, maka pemahaman akan fotografi khususnya dalam bidang jurnalistik harus diartikan. Fotografi jurnalistik adalah jenis fotografi yang memberitakan sebuah permasalahan yang sejujurnya kepada masyarakat (Way, 2014). Pemberitaan melalui media fotografi harus berdasarkan fakta yang ada dan tidak dibuat-buat. Foto jurnalistik menghentikan waktu dan memberi kita gambaran nyata bagaimana waktu membentuk sejarah. Oleh karena sifat dasarnya yang dokumentatif, foto jurnalistik mampu membuat masyarakat melihat kembali rekaman imaji atas apa yang telah mereka lakukan pada masa lalu, sekaligus memuat pertanyaan tentang apa yang akan terjadi di masa mendatang.

\section{Metode Penelitian}

Paradigma penelitian menggunakan konstruktivisme, sebagaimana halnya suatu kepercayaan atau prinsip dasar yang ada dalam diri seseorang mengenai suatu pandangan dunia, maka paradigma membentuk cara atau pola pandangnya terhadap dunia. Paradigma konstruktivis berbasis pada pemikiran umum tentang teori-teori yang dihasilkan oleh peneliti dan teoritis aliran konstruktivis (Wibowo, 2011).

Metode penelitian yang digunakan di dalam penelitian adalah metodologi penelitian kualitatif. Metodologi penelitian kualitatif dipilih untuk menentukan cara mencari, mengumpulkan, mengolah, dan menganalisis data pada hasil penelitian. Penelitian kualitatif yaitu penelitian yang bermaksud untuk memahami fenomena tentang apa yang dialami oleh subyek penelitian secara holistik, dan dengan cara deskripsi dalam bentuk kata-kata dan bahasa, pada suatu konteks khusus yang alamiah dan dengan memanfaatkan berbagai metode ilmiah 
(Moleong, 2014). Penelitian kualitatif juga merupakan metode dimana data diinterpretasikan melalui analisis pemaknaan (Turner \& West, 2008).

Teknik pengumpulan data yang digunakan dalam penelitian adalah studi dokumenter. Dalam pendekatan kualitatif, peneliti bekerja sebagai perencana, pelaksana pengumpulan data, analis, penafsir, dan pada akhirnya menjadi pelapor hasil penelitian (Indiawan, 2013). Keterkaitan antara obyek dan informan penelitian dengan peristiwa masa lalu ataupun peristiwa saat ini dapat diungkapkan dari beberapa hal, yaitu (1) Bagaimana hubungan antara bahan visual dan peristiwa masa lalu. (2) Apakah lingkungan sosial di sekitar obyek dan informan penelitian saat itu memiliki keterkaitan dengan sebuah pemaknaan yang dapat dilihat saat ini. (3) Apa makna bahan visual itu dalam kehidupan obyek dan informan penelitian saat itu dan sekarang. (4) Sejauh mana bahan visual itu memberi petunjuk kepada peneliti untuk menemukan informasi baru (Bungin, 2007).

Pada penelitian, teknik analisis data yang dipakai adalah analisis semiotik oleh Charles S. Pierce. Dimana teknik analisis diarahkan meneliti makna eksklusivitas pada foto cover majalah Tempo edisi 4351. Mengumpulkan data mengenai foto pada cover, lalu diolah secara kualitatif dan dihubungkan menggunakan semiotika Charles S. Pierce untuk mengetahui hubungan yang terjalin antara obyek, tanda, dan interpretasi dari tampilan pesan dalam foto tersebut.

Teknik keabsahan data pada penelitian adalah triangulasi, yaitu melihat suatu realitas dari berbagai sudut pandang atau perspektif dan dari berbagai segi sehingga menjadi lebih kredibel dan kuat. Triangulasi digunakan untuk menambah validitas penelitian yang menurut Denzin (dalam Suparno, 2010) menjadi empat macam yaitu peneliti, sumber, metode, dan teori. Pada penelitian ini, tringulasi yang dipakai adalah triangulasi dengan teori, yang menurut Lincoln dan Guba, berdasarkan anggapan bahwa fakta tidak dapat diperiksa derajat kepercayaannya dengan salah satu atau lebih teori. Dalam hal ini, jika analisis telah menguraikan pola, hubungan, dan menyertakan penjelasan yang muncul dari analisis, maka penting sekali untuk mencari tema atau penjelasan pembanding.

\section{Hasil Penemuan dan Diskusi}

Deskripsi temuan penelitian, dimulai terlebih dahulu dengan menampilkan sebuah karya foto jurnalistik yang diabadikan oleh salah satu fotografer Tempo, yaitu Aditia Noviansyah. 


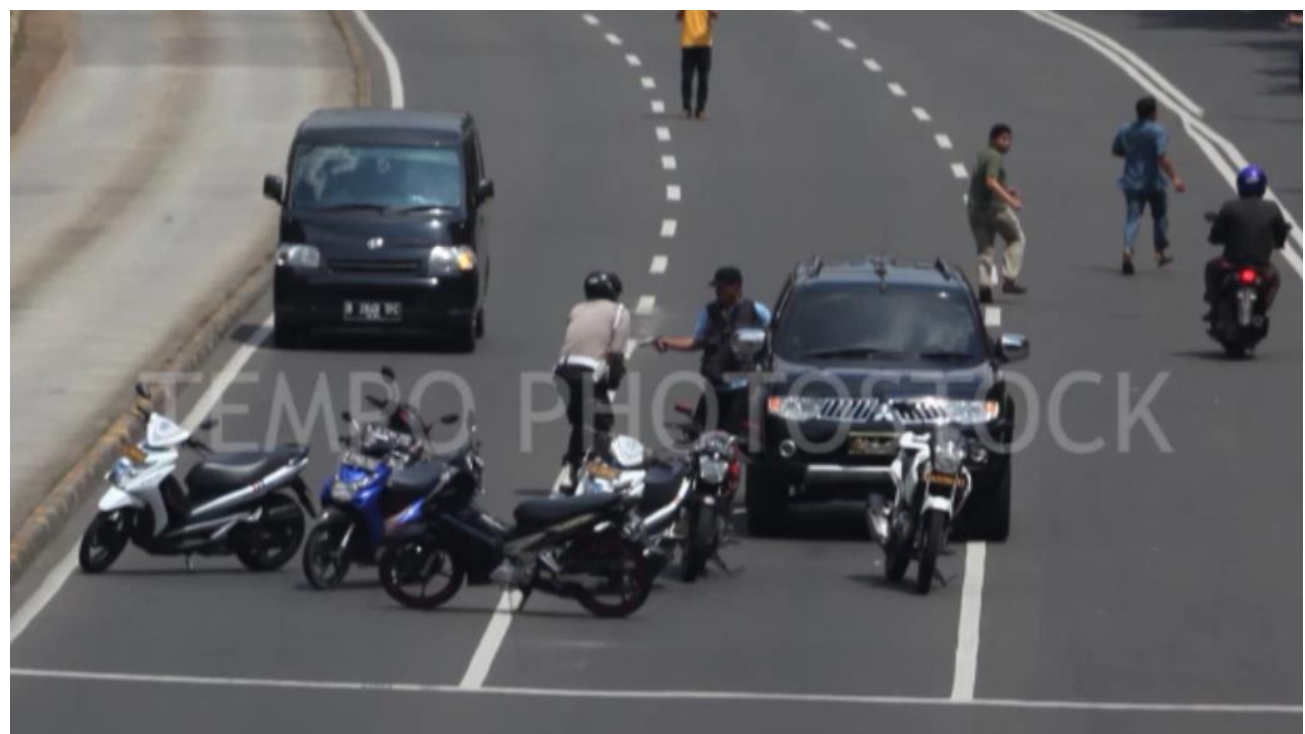

Gambar 2: Foto dokumentasi aksi teroris oleh Aditya Noviansyah

Dalam hal ini, redaktur Tempo memilih ratusan foto yang sudah diabadikan oleh beliau terkait teror bom Sarinah lalu diimplementasikan pada cover majalah Tempo edisi 4351 dengan memotong sebagian elemen yang tidak terlalu penting untuk dapat diperbesar obyek yang ada pada gambar tersebut, guna nilai berita yang disajikan akan menjadi nilai tambah dan memudahkan untuk mendeskripsikan lebih banyak jika dimasukkan visualisasi foto langsung pada obyek yang ingin diperlihatkan.

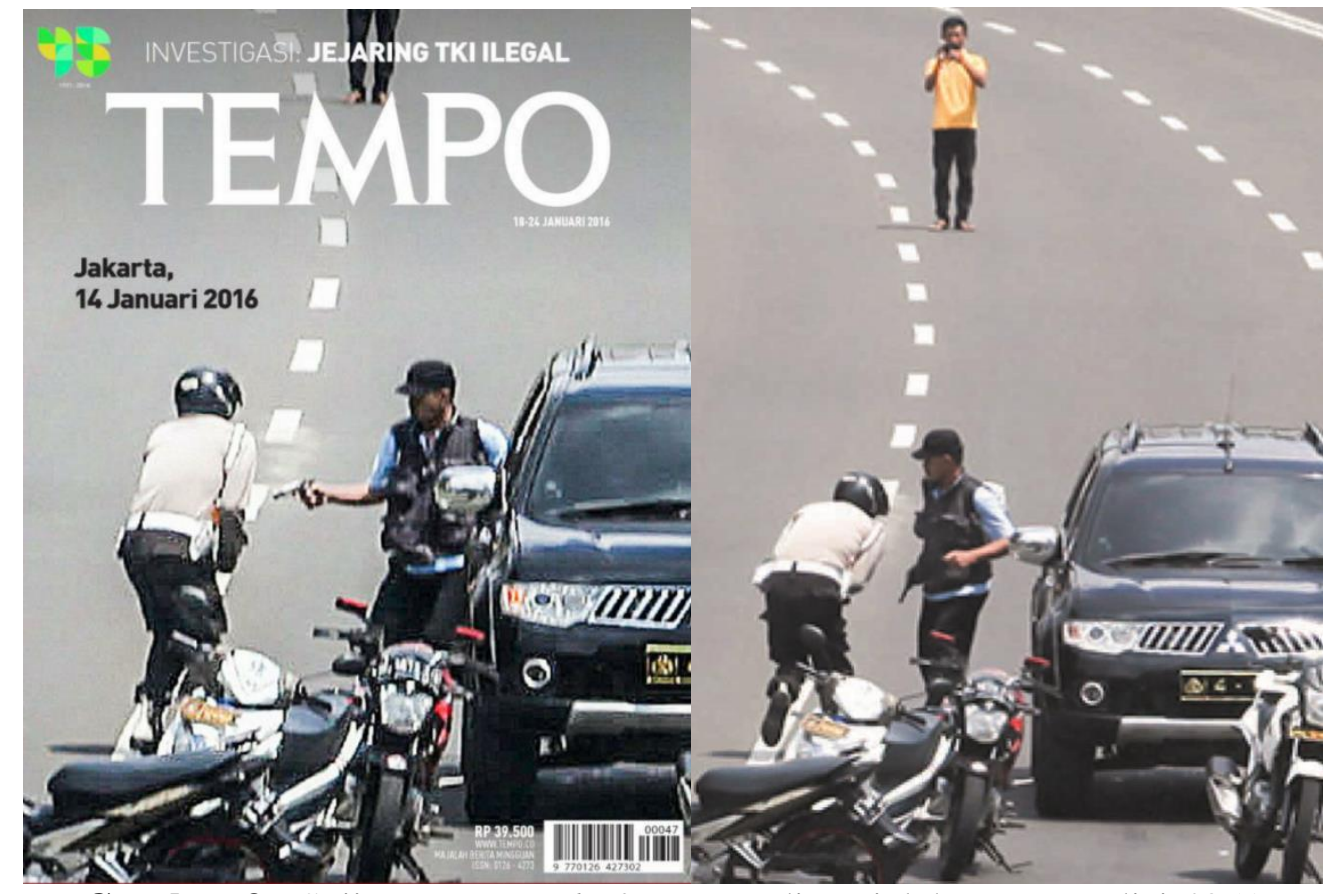

Gambar 3: Sajian cover and after story di Majalah Tempo edisi 4351 
Hasilnya dapat dilihat pada Gambar 3 sebelumnya. Hal tersebut dilakukan agar dapat terlihat lebih jelas seorang pria terduga teroris menembaki salah satu polisi. Selain memberitakan hal fresh yaitu berita yang sedang hangat diperbincangkan, nilai berita yang terdapat foto tersebut sangatlah tinggi, ini dikarenakan Aditia Noviansyah dapat mengambil sebuah kejadian dimana seorang pria terduga teroris, menggunakan kemeja biru, dengan rompi hitam dan topi hitam, menembaki seorang polisi, dari belakang mobil. Suatu peristiwa yang sangat jarang terjadi, terlebih dalam jurnalistik nasional baik itu cetak maupun elektronik.

Tempo secara terang-terangan memasang foto dengan obyek seseorang sedang menodongkan sebuah senjata api ke arah polisi pada cover-nya. Sebuah hal berbeda dan berani yang dilakukan oleh sebuah majalah bertaraf nasional. Pasalnya, sampai penelitian dibuat, tidak ada majalah nasional lainnya yang berani memberikan atau menayangkan sebuah foto dengan seseorang sedang menodongkan senjata api ke seseorang pada cover majalahnya, yang jika dilihat, tidak etis atau tidak pantas diterbitkan melihat bukan hanya kalangan dewasa saja yang melihat, tetapi berdampak pada kalangan di bawah umur jika kedapatan tidak sengaja melihat foto tersebut pada sebuah majalah.

Terdapat pula kata "TEMPO" sebagai penjelas bahwa majalah tersebut adalah majalah dari Tempo, lalu ada sebuah tulisan berupa "Investigasi: Jejaring TKI ilegal" yang merupakan salah satu berita pada isi majalah Tempo edisi 4351, dan tidak ketinggalan ada kata berupa "Jakarta, 14 Januari 2016" yang mengisyaratkan kejadian teror bom Sarinah yang berlangsung di Jakarta pada tanggal 14 bulan Januari tahun 2016. Berdasarkan obyek penelitian tersebut, maka dilakukanlah identifikasi triangle of meaning Charles S.Pierce dilihat pada setiap elemen yang ada pada obyek penelitian. Pada identifikasi obyek, sebuah foto jurnalistik yang lebih terarah sebagai foto spot news. Foto yang memperlihatkan seorang pria sedang menodongkan sebuah senjata api ke seorang polisi.

Icon; (1) Seseorang menggunakan rompi hitam, kemeja biru, topi hitam, dan memegang senjata api berwarna perak, (2) Seseorang yang sedikit membungkukkan badan dan tangan memegang daerah perut, (3) Sebuah mobil hitam berplatkan nomor polisi Indonesia, (4) Tiga buah sepeda motor, (5) Sepasang kaki, (6) Garis membujur putus-putus berwarna putih.

Index; (1) Pria yang menggunakan rompi hitam, kemeja biru, topi hitam, dan memegang senjata api berwarna perak adalah terduga teroris, (2) Pria yang menggunakan baju coklat lengan panjang, celana panjang coklat, memakai helm berwarna hitam, serta menggunakan ikat pinggang lengkap dengan berbagai alat perlengkapan adalah seorang polisi, (3) Tangan kanan seorang terduga teroris yang memegang senjata api ke arah bagian perut seseorang adalah sebuah aktivitas yang sedang dilakukan dan ditujukan kepada seorang polisi, (4) Polisi membungkukkan badan adalah sebuah aktivitas timbal balik yang telah dilakukan oleh terduga teroris. Hal ini menyangkut pada kegiatan timbal balik antara aktivitas yang dilakukan oleh terduga teroris kepada seorang polisi, (5) Sepasang kaki adalah seorang manusia yang sedang berdiri dekat terduga teroris dan seorang polisi, (6) Garis membujur putus- putus berwarna putih adalah sebuah tanda marka jalan yang berada pada jalan lalu lintas kendaraan, (7) Mobil hitam 
berplatkan polisi Indonesia adalah suatu kendaraan roda empat yang digunakan untuk membawa beberapa polisi ke suatu tempat, (8) Beberapa motor yang salah satunya berplatkan polisi Indonesia adalah suatu kendaraan roda dua yang digunakan oleh polisi untuk datang ke suatu tempat dengan lebih mudah dan cepat.

Symbol; (1) Terduga teroris menggunakan senjata api sebagai bentuk perlawanan yang selalu dilakukan oleh seorang teroris sebagai tanda kekuasaan serta pemberontakan kepada siapapun yang melawannya, (2) Polisi merupakan seseorang sosok yang dipercaya masyarakat sebagai pembawa keamanan dan kenyamanan dalam menjalani kehidupan karena menggunakan peralatan penunjang keamanan, serta menjadi simbol ketentraman di mata warga, (3) Nomor plat kendaraan berlambangkan polisi Indonesia menandakan bahwa kendaraan tersebut berasal dari negara Indonesia, (4) Marka jalan dengan tanda garis membujur merupakan suatu tanda jalur lalu-lintas dimana perkerasan jalan yang direncanakan khusus untuk lalu lintas kendaraan (Ditjen BM, 1992).

Setelah identifikasi obyek, dilajutkan pada identifikasi interpretan peneliti, yaitu foto dalam konteks jurnalistik ini merupakan perwujudan representasi salah satu terduga teroris yang sedang menembaki seorang polisi terhadap aksi teror bom di Sarinah, Jakarta. Kesan yang didapatkan pertama kali pada foto ini adalah sebuah kejadian mengerikan dimana seseorang terlihat sedang menembaki polisi di area perutnya.

Begitu pula terduga teroris yang secara bebas berada di belakang mobil berwarna hitam menggunakan plat nomor polisi, lalu secara kasat mata dapat dilihat memegang sebuah senjata api berwarna perak lalu mengarahkan senjata api tersebut ke polisi. Keputusan fotografer Tempo mengambil gambar pada posisi high angle dan penempatan elemen berada di center position, membuat setiap mata akan langsung tertuju pada elemen yang disajikan pada foto dalam cover majalah Tempo edisi 4351 sebagai suatu konten eksklusivitas.

Dalam foto tersebut memang tidak dapat merekam suara atau jeritan polisi yang terkena tembakan, tetapi kita dapat melihat dari gesture tubuh polisi yang membungkuk dan tangan memegang area perut, menandakan bahwa betapa sakitnya efek peluru yang ke luar dari senjata api terduga teroris mengenai tubuhnya (simak after story di sebelah kanan Gambar 3). Suatu kesan sebagai pembangkangan dan pemberontakan terduga teroris.

Dalam foto ini juga terdapat beberapa sepeda motor dan mobil berplatkan polisi Indonesia serta terlihat adanya marka jalan garis membujur putus-putus, dimana hal tersebut menandakan bahwa kejadian tersebut sedang berlangsung di salah satu jalan lalu lintas kendaraan negara Indonesia serta melibatkan salah satu korban yaitu seorang polisi Indonesia.

Hal ini juga sebagai bentuk suatu kejanggalan, dikarenakan ada beberapa motor yang terlihat terparkir di dekat terduga teroris dan seorang polisi dimana seharusnya di lokasi tersebut juga terdapat beberapa polisi dan yang lebih menjanggalkan adalah terdapat sebuah mobil berplatkan polisi Indonesia yang ada di antara mereka dimana dapat menampungkan polisi lebih banyak ketimbang sepeda motor ke lokasi kejadian. 
Hal ini menguatkan dugaan peneliti bahwa di lokasi kejadian, bukan hanya satu polisi saja, tetapi terdapat beberapa polisi yang berada di lokasi kejadian dan tidak jauh di antara terduga teroris dan seorang polisi. Tetapi kenyataan menjawab sebaliknya, dimana tidak ada satu orang polisi pun yang dapat melumpuhkan atau setidaknya menahan terduga teroris tersebut melancarkan tembakan ke salah seorang polisi.

Tak cukup sampai di situ, cover majalah Tempo ini juga merupakan hasil proses editing yaitu mengcropping foto aslinya (simak Gambar 2), dengan maksud membuang bagian-bagian foto yang tidak penting lalu disesuaikan seperti apa yang diinginkan oleh redaktur Tempo. Kegiatan yang dilakukan oleh Tempo adalah sesuatu yang wajar dilakukan oleh setiap media cetak, dikarenakan di era fotografi digital, cropping bisa mempunyai bahkan menambahkan nilai lebih pada foto hasil cropping, dimana sebuah foto bisa "menghasilkan" foto lain. Potongan sebuah foto bisa mempunyai makna yang berbeda dengan foto induknya dikutip dalam buku digital camera zona pro.

Hasil cropping yang dilakukan Tempo lebih kepada memperlihatkan terduga teroris sedang menembaki seorang polisi dengan lebih jelas serta di antara mereka terdapat kendaraan mobil milik polisi, tetapi hanya diperlihatkan setengahnya saja. Hal ini dilakukan oleh Tempo, dengan maksud adanya eksklusivitas yang terjadi, dikarenakan image polisi sebagai lambang keamanan, hancur seketika oleh aksi teroris.

Setelah mengidentifikasi obyek penelitian menggunakan triangle of meaning Charles Sanders Pierce, lalu dikaitkan pada triangulasi teori. Hal ini dilakukan, guna menganalisis nilai eksklusivitas yang muncul dalam teori konstruksi sosial yaitu mengenai kejadian ledakan bom Sarinah, Jakarta.

Pada teori konstruksi sosial, teori ini digunakan untuk melihat cara pandang serta maksud dan tujuan majalah Tempo dalam memberikan sebuah karya foto jurnalistik terkait kejadian bom Sarinah, Jakarta, pada cover edisi 4351. Selain itu, teori ini melihat bagaimana Tempo mengkonstrukkan buah pemikiran masyarakat dengan cara menampilkan sebuah foto jurnalistik ini pada sebuah cover majalah. Hasilnya adalah Konstruksi sosial di sini melihat sebuah media massa mengabarkan sesuatu yang dinilainya penting, bagi medianya itu sendiri serta bagi masyarakat luas.

Media dengan kekuatan informasi ditunjang dengan berita yang faktual, yang artinya kejadian tersebut memang benar terjadi, serta ditambah dengan data yang telah terkumpulkan, menjadikan pemberitaannya tersebut menjadi sebuah berita eksklusif untuk siap diterbitkan. Media tidak akan menunggu lama untuk mendapatkan kesempatan yang berharga tersebut.

Sebuah teks ditunjang dengan foto dalam media cetak adalah satukesatuan yang tidak dapat dipisahkan. Hal tersebut dilakukan khususnya media cetak untuk mempersepsikan buah pemikiran media kepada pembaca agar apa yang ingin disampaikan oleh media terealisasikan dengan baik serta pemikiran media itu dapat terelasikan dengan baik kepada pembaca. Dengan membuat konten atau pemberitaan menarik, dalam hal ini menggunakan teks dan foto, yang dapat menggiring para masyarakat untuk membaca pemberitaan tersebut. Terlebih, dewasa ini, masyarakat ingin suatu berita yang menarik dan sesuai fakta. 
Hal tersebutlah yang membuat sebagian media cetak memberitakan berita yang up-to-date, dikonstruksikan sebagai sebuah pemberitaan eksklusif agar dikemas dengan menarik dan sesuai fakta yang ada dan berbeda dengan media lain. Dengan cara seperti itulah, terciptanya presepsi seseorang akan berita tersebut, entah percaya atau tidak. Pada akhirnya, konstruksi sosial yang dibuat untuk menciptakan berita faktual, berbeda dengan lain, maksudnya berita yang tidak diketahui oleh media lain tetapi diberitakan oleh medianya sendiri, membuat masyarakat menjadi lebih tahu kebenaran yang terjadi. Kebenaran dari sesuatu hal akan apa yang terjadi, atau sebuah eksklusivitas berita, baik itu melalui teks atau foto, pastinya akan membuat pro dan kontra terhadap suatu berita. Pro dan kontra tersebut dalam kasus ini ditekankan pada foto-foto yang ditayangkan pada majalah Tempo edisi 4351, di mana foto-foto tersebut dengan sendirinya memberikan pesan dan kesan kepada khalayak yang membacanya.

Konstruksi sosial yang dilakukan oleh majalah Tempo itulah contohnya. Melakukan konstruksi realitas model peta analog, artinya membuat pemberitaan secara faktual dan eksklusif, serta tidak dibuat-buat dan mengikuti alur (Soekanto, 2014), serta dilihat dari tiga tahap peristiwa konstruksi menurut Berger dan Luckman (Bungin, 2008), yaitu (1) Eksternalisasi, tahap pertama ini dimana majalah Tempo memberitakan sebuah berita kronologis kejadian bom Sarinah pada tanggal 14 Januari 2016 ke dalam majalahnya edisi 4351 yang diterbitkan pada tanggal 18 Januari 2016, (2) Obyektivasi, pada tahap kedua, terjadi proses dimana khalayak termasuk peneliti melihat dan membaca apa yang telah diberitakan atau lebih kepada isi konten apa yang diberitakan oleh Tempo pada majalah edisi 4351 tentang kasus bom Sarinah 14 Januari 2016, (3) Internalisasi, pada tahap terakhir ini, kelanjutan dari tahap kedua dimana khalayak serta peneliti mempersepsikan penalarannya sendiri terhadap apa yang telah dilihat dan dibacanya pada isi pemberitaan yang dilakukan oleh Tempo pada majalah Tempo edisi 4351 tentang kasus bom Sarinah 14 Januari 2016. Akhirnya membuat persepsi orang berbeda-beda terhadap pesan dan konten yang diberitakan pada majalah Tempo edisi 4351.

Hal ini dapat dilihat dari proses pengambilan keputusan yang diambil oleh majalah Tempo menyertakan foto jurnalistik terkait kasus bom Sarinah, Jakarta, yang tidak dimiliki oleh media lain, yaitu eksklusivitas.

\section{Simpulan}

Berdasarkan hasil analisis yang dilakukan dengan obyek penelitiannya berupa cover majalah Tempo tentang tragedi bom Sarinah dengan obyek penelitiannya berasal dari hasil karya foto jurnalistik, menyatakan bahwa sebuah konstruksi realitas yang dilakukan majalah Tempo pada edisi 4351 dilihat dari eksklusivitas berita yang diberitakan. Hal tersebut dikarenakan terdapat sejumlah pesan yang terdapat pada cover yang diberitakan, yaitu foto yang memperlihatkan situasi mencekam dimana seseorang terlihat ditembak oleh seorang terduga teroris, lalu ada pemberontakan, dimana seseorang membangkang dan melawan peraturan-peraturan serta norma-norma yang ada, dengan menembaki seseorang, terlebih korban yang ditembakinya ialah berasal dari instansi keamanan, yaitu 
polisi, serta terdapat pesan eksklusivitas, dimana tidak berjalannya suatu roda kehidupan, dilihat dari jika suatu tempat terdapat instansi keamanan yaitu polisi, masyarakat merasa aman dan tentram dari mara bahaya. Tetapi dengan kejadian tersebut, memutar balikan semuanya. Dimana jika terdapat polisi di suatu tempat, tidak selalu serta merta membawa keamanan dan kenyamanan akan bahaya, bahkan polisi tersebut juga bisa menjadi salah satu korban dari aksi teroris.

Sebuah karya fotografi jurnalistiklah yang dimanfaatkan oleh majalah Tempo dalam mengemas pemberitaan aksi teror bom di Sarinah Jakarta, guna menarik perhatian masyarakat luas untuk dapat membaca pemberitaannya tersebut.

Hal inilah yang membuat penulis dapat menyimpulkan bahwa foto jurnalistik pada cover majalah Tempo edisi 4351, memberikan berbagai pesan subyektif dari peneliti tercermin dari setiap elemen yang ada pada foto tersebut dan sebuah makna obyektif terkandung di dalamnya, yakni sebuah nilai eksklusivitas. Foto yang diberitakan oleh majalah Tempo edisi 4351 bukan tanpa sebab, melainkan sebuah hasil karya fotografi jurnalistik, dapat merekam sebuah peristiwa dengan sangat cepat dan tidak dapat direkam oleh penglihatan manusia, serta dapat memberikan suatu tinjauan serta gambaran jelas terhadap suatu peristiwa yang sedang terjadi, dan tidak dimiliki oleh pihak manapun.

\section{Ucapan terima kasih}

Riset ini dapat terselenggara dengan baik berkat dukungan dari pihak Majalah Tempo serta segenap tim di dalamnya, terutama mas Bekti Nugroho yang bersedia memberi keterangan tambahan dan Aditya Noviansyah selaku Fotografer yang karyanya kami teliti. Selain itu, kolega dalam berdiskusi fotografi di lingkup Universitas Bunda Mulia: Fransiscus Xaverius Damarjati, S.Sn., M.Sn., Ignasius Liliek Senaharjanta, S.Sn., M.Ikom., dan Sri Wahyuning Septarina, S.Ds., M.Ds.

\section{Daftar Pustaka}

Bungin, M Burhan. (2007). Penelitian Kualitatif. Jakarta (ID): Kencana Prenada Media Group.

Bungin, M Burhan. (2008). Sosiologi Komunikasi: Teori, Paradigma, dan Diskursus Teknologi Komunikasi di Masyarakat. Jakarta (ID): Kencana Prenada.

[Dir PJK] Direktorat Pembinaan Jalan Kota. (1992). Tata Cara Pemasangan Rambu Dan Marka Jalan Perkotaan. Jakarta (ID): Direktorat Jenderal Bina Marga dan Direktorat Pembinaan Jalan Kota.

Hamad, Ibnu. (2004). Konstruksi Realitas Politik dalam Media Massa: Sebuah Studi Critical Discourse Analysis terhadap Berita-berita Politik. Jakarta: Granit

Moleong, Lexy J. (2014). Metodologi Penelitian Kualitatif. Bandung (ID): Remaja Rosdakarya.

Safanayong, Yongky. (2011). Desain Komunikasi Visual Terpadu. Jakarta (ID): Arte Intermedia. 
Sobur, Alex. (2006). Semiotika Komunikasi. Bandung (ID): PT Remaja Rosdakarya.

Soekanto, Soerjono. (2014). Sosiologi suatu Pengantar. Jakarta (ID): Rajagrafindo Persada.

Suparno, Paul. (2010). Filsafat Konstruktivisme dalam Pendidikan. Yogyakarta (ID): Kanisius.

Turner, Lynn H dan Richard West. (2008). Pengantar Teori Komunikasi Analisis dan Aplikasi. Jakarta (ID): Salemba Humanika.

Way, Wilsen. (2014). Human Interest Photography : Mengungkapkan Sisi Kehidupan Secara Langsung dan Jujur. Jakarta (ID): Elex Media Komputindo.

Wibowo, Indiwan Seto Wahyu. (2011). Semiotika Komunikasi: Aplikasi Praktis Bagi Penelitian dan Skripsi Komunikasi. Jakarta: Mitra Wacana Media

Wijaya, Taufan. (2014). Foto Jurnalistik Dalam Dimensi Utuh. Jakarta (ID): Sahabat. 